\title{
Differential acclimation responses to irradiance and temperature in two co-occurring seaweed species in Arctic fjords
}

\author{
Johanna Marambio ${ }^{1,2,3}$ \& Kai Bischof ${ }^{1,4}$ \\ ${ }^{1}$ Marine Botany, University of Bremen, Bremen, Germany \\ ${ }^{2}$ Laboratory of Antarctic and Sub-Antarctic Marine Ecosystems, Department of Sciences, University of Magallanes, Punta Arenas, Chile \\ ${ }^{3}$ Functional Ecology, Alfred Wegener Institute for Polar and Marine Research, Bremerhaven, Germany \\ ${ }^{4}$ Center for Marine Environmental Sciences, University of Bremen, Bremen, Germany
}

\begin{abstract}
Arctic fjord systems experience large amplitudes of change in temperature and radiation regime due to climate warming and the related decrease in sea ice. The resultant increase in irradiance entering the water column influences photosynthetic activity of benthic and pelagic primary producers. The subtidal brown alga Desmarestia aculeata and the intertidal red alga Palmaria palmata populate the cold-temperate coasts of the North Atlantic, reaching the polar zone. To evaluate their acclimation potential, we collected both species in Kongsfjorden, Svalbard $\left(78.9^{\circ} \mathrm{N}, 11.9^{\circ} \mathrm{E}\right)$, during the Arctic summer and exposed specimens to two different PAR levels (50 and $500 \mu \mathrm{mol}$ photons $\mathrm{m}^{-2} \mathrm{~s}^{-1}$ ) and temperatures $\left(0,4\right.$ and $\left.8{ }^{\circ} \mathrm{C}\right)$ for 21 days. Photosynthetic parameters and biochemical features (pigment concentration and antioxidants) were assessed. In general, high irradiance was the factor that generated a negative effect for $D$. aculeata and $P$. palmata in the photosynthetic parameters of the photosynthesis-irradiance curve and $F_{\mathrm{v}} / F_{\mathrm{m}}$. The pigment concentration in both species tended to decrease with increasing irradiance. Antioxidant level showed different trends for both species: in D. aculeata, antioxidant potential increased with high irradiance and temperature, while in P. palmata, it only increased with high irradiance. Both species showed responses to the interaction of irradiance and temperature, although $D$. aculeata was more sensitive to high irradiance than P. palmata. Our study shows how these species, which have similar geographical distribution in the North Atlantic and the Arctic but belong to different taxonomic lineages, have similar strategies of acclimation, although they respond differently to ecophysiological parameters.
\end{abstract}

To access the supplementary material, please visit the article landing page

\section{Keywords}

Arctic; Desmarestia aculeata; Palmaria palmata; photosynthesis; temperature: irradiance

\section{Correspondence}

Johanna Marambio, Marine Botany, University of Bremen, Leobener Str. NW2, 28359 Bremen, Germany. E-mail: marambio@ uni-bremen.de

\author{
Abbreviations \\ $\alpha$ : photosynthetic efficiency \\ ANOVA: analysis of variance \\ Anthera: antheraxanthin \\ Apc: allophycocyanin \\ $\beta$-car: $\beta$-carotene \\ chl $a$ : chlorophyll $a$ \\ chl c2: chlorophyll c2 \\ DPPH: 2,2-diphenyl-1-picrylhydrazyl \\ DPS: de-epoxidation state \\ DW: dry weight \\ Ek: saturation irradiance \\ Fuco: fucoxanthin \\ $F_{V} F_{m}$ : maximal quantum yield of PSII \\ Lut: lutein \\ PAR: photosynthetically active radiation \\ PC: phycocyanin \\ Pe: phycoerythrin \\ PSII: photosystem II \\ P-E: photosynthesis-irradiance \\ rETRmax: maximum relative electron \\ transport rate \\ ROS: reactive oxygen species \\ SD: standard deviation \\ TE: Trolox equivalent \\ Trolox: 6-hydroxy-2,5,7,8- \\ tetramethylchroman-2carboxylic acid \\ Tukey's HSD: Tukey's honestly significant \\ difference test \\ UV: ultraviolet \\ VAZ: violaxanthin, antheraxanthin, zeaxanthin \\ Viol: violaxanthin \\ Zeax: zeaxanthin
}

\section{Introduction}

The Arctic is characterized by a dynamic climate history, which has been marked by several glacial processes (Miller et al. 2009). The current warming process in the
Arctic is two times higher than the global average, and this condition is strongly related to the increase in surface air temperature (He et al. 2019), also called Arctic Amplification (Serreze \& Francis 2006; He et al. 2019). The Svalbard archipelago is currently considered as a model 
region for studies of transitions in the atmospheric, terrestrial and marine realm. Here, the fjord Kongsfjorden has been particularly intensively studied as a natural laboratory to observe climate imprints on marine Arctic communities (Wiencke \& Hop 2016), and it has been suggested as a harbinger of change in a pan-Arctic perspective (Bischof et al. 2019).

In the coastal habitat of Arctic fjord systems, macroalgae represent ecosystem engineering organisms of utmost ecological significance, and the response of macroalgal communities towards environmental change is crucial for future ecosystem function particularly in high-latitude fjord systems (Krause-Jensen et al. 2015). In these habitats, macroalgal communities are under strong control by seasonally changing abiotic drivers. Francis $\&$ Hunter (2006) describe how the increase in temperature over the past few decades has led to a significant decline in Arctic sea-ice cover, and Wiencke et al. (2006) described how sea-ice conditions modulate the underwater radiation climate. This has raised a number of questions, mainly related to the effect of light availability on photosynthesizing organisms in the water column and on the seafloor (Hanelt et al. 2001). Macroalgae in the Arctic have to react to strong seasonal variations and have, therefore, developed a wide range of physiological plasticity (Karsten et al. 2003). Bringloe et al. (2020) highlight the complex evolutionary process of marine benthic species around the Arctic, suggesting that a large number of algal species do not simply tolerate high latitude conditions but are adapted to them.

The Kongsfjorden area is increasingly influenced by the warm water current coming from the western Atlantic, generating a strong interface with the characteristics of High-Arctic waters (Bischof et al. 2019). Kongsfjorden's algal community is likely to change in correspondence to the specific temperature requirements of the species involved (Bartsch et al. 2016). In contrast to the Antarctic marine flora, Arctic-dwelling macroalgal species exhibit a low level of endemism (Wulff et al. 2011 ), and most of the inhabiting species are cold-tolerant extensions of populations found in temperate zones (Bringloe et al. 2020). However, to thrive in such high latitudes, macroalgal species have to be adapted to cope with strong seasonality in light climate and year-round low temperatures (Wiencke et al. 2011; Zacher et al. 2011; Wiencke \& Amsler 2012). Overall, Arctic fjord systems are marked by high macroalgal species diversity, and Fredriksen et al. (2019) reported a total of 197 macroalgal species for the Svalbard archipelago, with 84 species occurring in Kongsfjorden. Ongoing changes in abiotic drivers will presumably affect competitive interactions among macroalgae and generate shifts in community structure.
Besides kelp, the phaeophyte Desmarestia aculeata (Linnaeus) J. V. Lamouroux and the rhodophyte Palmaria palmata (Linnaeus) Kuntze (Rhodophyta, Palmariaceae) are frequently present in Arctic fjord systems but rarely studied at this high latitude. Palmaria palmata has a distribution around the North Atlantic Ocean, mainly found in rocky shore environments, from the intertidal to the shallow subtidal zone (MacArtain et al. 2007; Bjarnadóttir et al. 2018). A large number of studies of $P$. palmata in North America and Europe are strongly related to its use in the feeding of abalone in hatcheries (Le Gall et al. 2004). It is also sought after for its high content of fibre, vitamins, minerals, proteins (Lahaye et al. 1993) and antioxidants (Wang et al. 2010) and for its anti-inflammatory effects (Lee et al. 2017).

Desmarestia aculeata mainly inhabits the subtidal zone, is an opportunistic alga at the time of habitat colonization and is frequently found in association with other species in the same genus (Kain \& Jones 1975) as well as other large brown algae, such as Saccharina latissima, Laminaria hyperborea, among others (Pehlke \& Bartsch 2008). This species has previously been included in ecological studies and species lists in the North Atlantic, for example, by Mathieson $\delta$ Dawes (2017) and Nielsen $\delta$ Lundsteen (2019), who conducted a review of the genus Desmarestia off the coast of Russia. Some specific studies have been carried out on the species $D$. aculeata, both in the laboratory and in the field, in order to understand ecophysiological patterns in relation to the seasonality of the species (Chapman \& Burrows 1970; Bischof et al. 2002).

Both $D$. aculeata and P. palmata have a perennial life cycle (Hop et al. 2002) and, therefore, undergo a series of adaptive adjustments to cope with the changes in irradiance and temperature during the course of the year. In general, the photosynthetic rate of Arctic macroalgae is affected by a series of abiotic factors (Hurd et al. 2014). Although irradiance is a vital factor for these organisms, excess light can generate photoinhibition (Hurd et al. 2014). This is mainly due to the photo-oxidation of photosynthetic pigments and proteins, by the formation of ROS, increased fragmentation of photosystem II or decreased turn-over of the Dl protein (Aro et al. 1993). With regard to temperature, macroalgae in the Arctic are generally not strictly adapted to low temperatures (Hurd et al. 2014), with the exception of some Arctic endemic species, such as Laminaria solidungula (Dunton \& Dayton 1995). Variations in temperature directly influence developmental processes, for example, spore germination (Müller et al. 2008). The wide distribution range of most species found in the Arctic suggests that increased temperature will not be a determining factor in the survival of these species per se (Hurd et al. 2014). However, it is expected that increases in temperature may affect other 
environmental variables, which may, in turn, affect the ecology of the species in a negative or positive way.

The large number of studies carried out on species that form underwater forests (kelps) in the High Arctic contrasts with the scarcity of ecological and physiological studies of other macroalgal species that are associated with these forests or their peripheries and that might also play an important role in ecological networks. So far, the focus of research on P. palmata in the Arctic has been mainly on physiology (Hanelt \& Nultsch 1995; Holzinger et al. 2004), UV effects (Karsten \& Wiencke 1999; Van De Poll et al. 2002; Karsten et al. 2003) and the seasonal variation of ecophysiological patterns (Aguilera et al. 2002). Arctic specimens have also been studied with respect to their responses to increased temperature and $\mathrm{CO}_{2}$ (Gordillo et al. 2016). Still, many aspects involved in the acclimation process of P. palmata in a changing Arctic are unresolved.

The brown alga $D$. aculeata is another species found in the Arctic that has been less studied, although it is abundant and ecologically valuable (Lippert et al. 2001). Some studies conducted on this species in the Arctic have focused on seasonal variation and biochemical response to increased light intensity (Aguilera et al. 2002) and on its response to increased $\mathrm{CO}_{2}$ combined with increasing temperature (Iñiguez et al. 2015; Gordillo et al. 2016).

The main objective of the present study was to investigate the effects of the combined change in two environmental drivers-temperature and irradiance-on D. aculeata and P. palmata, two understudied macroalgal species in a High-Arctic fjord system. For both species, we studied the consequences of variation in temperature and irradiance to photosynthetic performance and set out to reveal the physiological adjustments and limits of acclimation. On the basis of their similar geographic distribution, but with slightly different vertical habitat preference, we hypothesized that both species will most likely not be adversely affected by the current increase in temperature in the Arctic but might respond differently with respect to variation in light.

\section{Material and methods}

Two species of Arctic seaweeds were collected for this study, Desmarestia aculeata and Palmaria palmata. The experiment was carried out in July 2019 in the Kings Bay Marine Laboratory, Ny-Ålesund, Spitsbergen, Svalbard (78.9 N, 11.9 E; Supplementary Fig. S1). Algal material was collected at two sites. Specimens of $D$. aculeata were collected at Brandal $\left(78^{\circ} 56^{\prime} 49.25^{\prime \prime} \mathrm{N}\right.$; $\left.11^{\circ} 51^{\prime 2} 25.03^{\prime \prime} \mathrm{E}\right)$ by SCUBA diving at 5-6 $\mathrm{m}$ depth, and specimens of P. palmata were collected in the shallow subtidal in front of the Marine Laboratory $\left(78^{\circ} 55^{\prime} 39.8^{\prime \prime} \mathrm{N}\right.$; $\left.11^{\circ} 55^{\prime} 48.3^{\prime \prime} \mathrm{E}\right)$ at 0-1 m depth (Supplementary Fig. S1). For both species, apical fragments from vegetative fronds were selected. For $D$. aculeata, young sporophytes were used, while for P. palmata, vegetative gametophyte material was collected.

Fronds of both species were maintained in a "pre-control treatment," in 1-L seawater (34 psu) tanks enriched with PES-Provasoli; the medium was renewed every four days. Control samples were under constant illumination at $50 \mu \mathrm{mol}$ photons $\mathrm{m}^{-2} \mathrm{~s}^{-1}$ and at three different temperatures 0,4 and $8{ }^{\circ} \mathrm{C}$ for seven days. After this period of acclimation, some of the fronds were maintained in control light conditions, and the other fronds were transferred at $500 \mu \mathrm{mol}$ photons $\mathrm{m}^{-2} \mathrm{~s}^{-1}$ for a period of 21 days. Three independent replicate fronds were used per treatment.

\section{Photosynthetic performance}

Variable chl $a$ fluorescence of PSII was measured with a pulse amplitude-modulated chlorophyll fluorometer (Imaging PAM, Walz). The maximal quantum yield of PSII $\left(F_{\mathrm{v}} / F_{\mathrm{m}}\right)$ was measured after 10 min of dark-adaptation. Immediately after, rapid light curves (P-E) were measured: algal samples were irradiated with an increasing actinic irradiance (between 0 and $600 \mu \mathrm{mol}$ photons $\mathrm{m}^{-2} \mathrm{~s}^{-1}$ ) every $30 \mathrm{~s}$ (Schreiber et al. 1995). From the P-E curves, the following parameters were calculated: photosynthetic capacity expressed as maximum relative electron transport rate (rETRmax), saturation irradiance $(E \mathrm{k})$ and photosynthetic efficiency ( $\alpha$, initial linear slope). The hyperbolic (P-E) curves were fitted according to the equation of Platt et al. (1980), using the KaleidaGraph version 4.0 (Synergy Software).

\section{Pigment analyses}

The extraction of photosynthetic and accessory pigments $(n=3)$ was performed following the method of Koch et al. (2015). Algal material was frozen in liquid nitrogen, lyophilized for $24 \mathrm{hr}$ and pulverized for $20 \mathrm{~s}$ in a high-speed homogenizer (Fast prep®-24; MP Biomedicals). Between 0.05 and $0.1 \mathrm{~g}$ of biomass was extracted in $1 \mathrm{ml}$ acetone $(90 \%, \mathrm{v} / \mathrm{v})$, and the samples were kept at $4{ }^{\circ} \mathrm{C}$ for $24 \mathrm{hr}$ in darkness and finally analysed using a Hitachi LaChromeElite ${ }^{\circledR}$ high-performance liquid chromatography system. The system was equipped with a chilled autosampler L-2200 and a DAD detector L-2450 (VWR-Hitachi International). Separation of pigments was performed according to methods described by Wright et al. (1991) and Diehl et al. (2020).

For D. aculeata, the following pigments were measured: chl $a$ and chl $c 2, \beta$-car and Fuco, and VAZ, the pigments of the xanthophyll cycle. The DPS of the xanthophyll cycle was calculated according to the method of Colombo-Pallotta et al. (2006). 
For P. palmata, the following pigments were quantified by HPLC: chl $a$, Lut and $\beta$-car. Phycobilipigments were extracted, $300 \mathrm{mg}$ of algal biomass per replicate, and were ground and diluted in $50 \mathrm{mM}$ phosphate buffer, $\mathrm{pH}$ 5.5 , at $4{ }^{\circ} \mathrm{C}$. This solution was centrifuged for $20 \mathrm{~min}$ at $10.000 \times \mathrm{g}$ and $4^{\circ} \mathrm{C}$ to obtain a phycobiliprotein supernatant. The absorption was measured in a microplate reader (Fluostar Optima, BMG Labtech). The concentration of the phycobilipigments Pe, Apc and Pc was determined by absorption measurements at wavelengths of 498.5, 614 and $651 \mathrm{~nm}$ following the equation of Kursar et al. (1983). Pigment concentration was expressed in $\mu \mathrm{g} \mathrm{g}^{-1} \mathrm{DW}$.

\section{Antioxidant analysis}

The antioxidant activity was measured by applying the free radical DPPH (Sigma-Aldrich) assay, following the protocol of Brand-Williams et al. (1995), and modified by Cruces et al. (2012) and Koch et al. (2016). For the standard solution, the Trolox (Sigma-Aldrich) was used. This analysis was applied for both species, D. aculeata and P. palmata, and $0.5 \mathrm{mg}$ of freeze-dried biomass per sample $(n=3)$ was used in the extraction. The antioxidant activity of the samples was estimated from triplicate subsamples and expressed as TE ( $\left.\mathrm{mg} \mathrm{g}^{-1} \mathrm{DW}\right)$.

The concentration of phlorotannins in D. aculeata was determined as presented by Springer et al. (2017), using the Folin-Ciocalteu method described by Cruces et al. (2012). Purified phloroglucinol (Sigma-Aldrich) was used for the standard. Twenty milligram of freeze-dried biomass per sample $(n=3)$ was extracted in $1 \mathrm{ml}$ of acetone $(70 \% \mathrm{v} / \mathrm{v})$ and kept at $4{ }^{\circ} \mathrm{C}$ for $24 \mathrm{hr}$ in darkness. For quantification, absorption was measured at $\lambda=730 \mathrm{~nm}$ in a microplate photometer using three aliquots per replicate. The results were expressed in $\mathrm{mg} \mathrm{g}^{-1} \mathrm{DW}$.

Results for both species were analysed separately. To test for differences and interactions between temperatures and light treatments, the data were tested for normal distribution (Shapiro-Wilk test; $p<0.05$ ). In cases of non-normal distribution, data were log-transformed. For data with normal distribution two-factorial ANOVA, two-way ANOVA was carried out. When the test revealed significant differences, a post-hoc Tukey's HSD test was applied. The statistical analyses were run using RStudio (version 1.1.383, Boston, MA).

\section{Results}

\section{Photosynthetic performance}

The maximal quantum yield $\left(F_{\mathrm{v}} / F_{\mathrm{m}}\right)$ in $D$. aculeata decreased in both irradiances compared to the initial control treatment after 21 days of culture; this was observed at all temperatures. Significant differences were observed between the initial control treatment compared to the 50 and $500 \mu \mathrm{mol}$ photons $\mathrm{m}^{-2} \mathrm{~s}^{-1}$ treatments at all temperatures. No differences were observed between treatments due to temperature. For $P$. palmata, a significant decrease in $F_{\mathrm{v}} / F_{\mathrm{m}}$ was observed between the initial control and the high light treatment after 21 days at 4 and $8{ }^{\circ} \mathrm{C}$. Also, initial control samples and specimens under $50 \mu \mathrm{mol}$ photons $\mathrm{m}^{-2} \mathrm{~s}^{-1}$ showed significantly higher values at $8{ }^{\circ} \mathrm{C}$ compared to samples at 0 and $4{ }^{\circ} \mathrm{C}$ (Table 1, Supplementary Table S1).

Photosynthetic parameters as obtained from P-E curves were affected by the experimental treatments as follows. When comparing $\alpha$ in $D$. aculeata, significant differences were observed between light intensities at $0{ }^{\circ} \mathrm{C}$, as a decrease in values was observed at 50 and $500 \mu \mathrm{mol}$ photons $\mathrm{m}^{-2} \mathrm{~s}^{-1}$ treatments after 21 days of culture. For $\alpha$ in P. palmata, there was a significant decrease in specimens under $500 \mu \mathrm{mol}$ photons $\mathrm{m}^{-2} \mathrm{~s}^{-1}$ at $0{ }^{\circ} \mathrm{C}$, while at $4{ }^{\circ} \mathrm{C}$, the values tended to decrease at 50 and $500 \mu \mathrm{mol}$ photons $\mathrm{m}^{-2} \mathrm{~s}^{-1}$ compared to initials. At $8{ }^{\circ} \mathrm{C}$, there were no significant variations observed with respect to light intensity. With regard to temperature, significant differences were observed with the $500 \mu \mathrm{mol}$ photons $\mathrm{m}^{-2} \mathrm{~s}^{-1}$ treatments at $0{ }^{\circ} \mathrm{C}$ and the initial control at $4{ }^{\circ} \mathrm{C}$, compared to the other treatments analysed (Table 1, Supplementary Table S1).

The rETRmax in D. aculeata showed a tendency to decrease with increasing light intensity at all temperatures; significant differences were observed between the initial control and the 50 and $500 \mu \mathrm{mol}$ photons $\mathrm{m}^{-2} \mathrm{~s}^{-1}$ treatments at all temperatures. No significant differences were observed between temperatures.

The increase in light intensity tended to negatively affect the rETRmax values in P. palmata at $0{ }^{\circ} \mathrm{C}$, while at $4{ }^{\circ} \mathrm{C}$, the values tended to decrease with both irradiances after 21 days of cultivation; significant differences were observed between the initial control treatment and the other irradiances. With respect to the temperature factor, only significant differences were recorded for the $500 \mu \mathrm{mol}$ photons $\mathrm{m}^{-2} \mathrm{~s}^{-1}$ treatment at $0{ }^{\circ} \mathrm{C}$ and the initial control treatment at $4{ }^{\circ} \mathrm{C}$ (Table 1, Supplementary Table $\mathrm{Sl}$; two-way ANOVA, Tukey HSD, $p<0.05)$.

In $D$. aculeata, $E \mathrm{k}$ tended to be lower at 50 and $500 \mu \mathrm{mol}$ photons $\mathrm{m}^{-2} \mathrm{~s}^{-1}$ when compared to the initial control treatment. This pattern was visible at 0 and $4{ }^{\circ} \mathrm{C}$. At $8{ }^{\circ} \mathrm{C}$, after 21 days of culture, the samples at 50 and $500 \mu \mathrm{mol}$ photons $\mathrm{m}^{-2} \mathrm{~s}^{-1}$ showed no major variations in $E \mathrm{k}$ between them and the initial control treatment (Table 1, Supplementary Table S1). Palmaria palmata tended to present lower values of Ek with increasing light intensity at 0 and $4{ }^{\circ} \mathrm{C}$. However, no significant differences between light treatments were observed. Overall, significantly higher values of Ek were recorded at $0{ }^{\circ} \mathrm{C}$ 
Table 1. Photosynthetic parameters measured $(n=3)$ for Desmarestia aculeata and Palmaria palmata: $F_{v} / F_{m}$ and the parameters obtained from P-E curves, $\alpha$, rETRmax and Ek. Measured at three different temperatures $\left(0,4\right.$ and $\left.8^{\circ} \mathrm{C}\right)$ and different light intensities: control (initial control measure $50 \mu \mathrm{mol}$ photons $\mathrm{m}^{-2} \mathrm{~s}^{-1}$ ), 50 and $500 \mu \mathrm{mol}$ photons $\mathrm{m}^{-2} \mathrm{~s}^{-1}$ (after 21 days of culture). Different letters indicate significant differences among treatments $(p<0.05)$.

\begin{tabular}{|c|c|c|c|c|c|}
\hline Temp. $\left({ }^{\circ} \mathrm{C}\right)$ & Treatment & $F_{v} / F_{m}$ & $\begin{array}{c}\text { Initial slope }(\alpha) \\
\left(\mu \mathrm{mol} \text { photons } \mathrm{m}^{-2} \mathrm{~s}^{-1}\right)^{-1}\end{array}$ & rETRmax (rel. units) & $\begin{array}{l}\text { Saturating point (Ek) } \\
\left(\mu \mathrm{mol} \text { photons } \mathrm{m}^{-2} \mathrm{~s}^{-1}\right)\end{array}$ \\
\hline \multicolumn{6}{|l|}{ D. aculeata } \\
\hline \multirow[t]{3}{*}{0} & Control & $0.61( \pm 0.03)^{a b c}$ & $0.20( \pm 0.02)^{a}$ & $14.37( \pm 1.67)^{a}$ & $72.58( \pm 14.33)^{\mathrm{ab}}$ \\
\hline & 50 & $0.41( \pm 0.02)^{\mathrm{de}}$ & $0.12( \pm 0.02)^{b c}$ & $10.84( \pm 2.47)^{\mathrm{bc}}$ & $64.31( \pm 13.69)^{\mathrm{abcd}}$ \\
\hline & 500 & $0.14( \pm 0.02)^{\mathrm{e}}$ & $0.08( \pm 0.02)^{c}$ & $3.14( \pm 0.54)^{c}$ & $39.81( \pm 11.29)^{c d}$ \\
\hline \multirow[t]{3}{*}{4} & Control & $0.59( \pm 0.01)^{\mathrm{a}}$ & $0.19( \pm 0.03)^{\mathrm{ab}}$ & $12.73( \pm 2.41)^{a}$ & $67.74( \pm 18.80)^{\mathrm{abc}}$ \\
\hline & 50 & $0.53( \pm 0.05)^{\mathrm{bc}}$ & $0.24( \pm 0.02)^{a b c}$ & $8.47( \pm 0.77)^{b c}$ & $39.24( \pm 10.69)^{\mathrm{bcd}}$ \\
\hline & 500 & $0.16( \pm 0.04)^{\mathrm{e}}$ & $0.12( \pm 0.04)^{b c}$ & $3.06( \pm 1.04)^{c}$ & $26.83( \pm 5.49)^{d}$ \\
\hline \multirow[t]{3}{*}{8} & Control & $0.60( \pm 0.01)^{\mathrm{ab}}$ & $0.17( \pm 0.03)^{\mathrm{ab}}$ & $11.58( \pm 3.63)^{a}$ & $68.68( \pm 16.12)^{a}$ \\
\hline & 50 & $0.47( \pm 0.05)^{c d}$ & $0.20( \pm 0.05)^{\mathrm{ab}}$ & $12.71( \pm 1.35)^{b c}$ & $64.02( \pm 13.82)^{\mathrm{abc}}$ \\
\hline & 500 & $0.16( \pm 0.04)^{\mathrm{e}}$ & $0.13( \pm 0.05)^{b c}$ & $8.68( \pm 0.76)^{b}$ & $69.26( \pm 18.10)^{\mathrm{abc}}$ \\
\hline \multicolumn{6}{|l|}{ P. palmata } \\
\hline \multirow[t]{3}{*}{0} & Control & $0.27( \pm 0.02)^{b c}$ & $0.09( \pm 0.04)^{\mathrm{ab}}$ & $4.82( \pm 0.96)^{\mathrm{bcd}}$ & $75.91( \pm 8.91)^{a b}$ \\
\hline & 50 & $0.27( \pm 0.01)^{b c}$ & $0.08( \pm 0.02)^{\mathrm{ab}}$ & $4.75( \pm 0.37)^{\mathrm{bcd}}$ & $61.85( \pm 12.44)^{\mathrm{ab}}$ \\
\hline & 500 & $0.19( \pm 0.05)^{c}$ & $0.05( \pm 0.02)^{c}$ & $2.40( \pm 0.24)^{d}$ & $51.31( \pm 11.79)^{a}$ \\
\hline \multirow[t]{3}{*}{4} & Control & $0.38( \pm 0.01)^{b}$ & $0.18( \pm 0.02)^{d}$ & $5.92( \pm 0.69)^{\mathrm{ab}}$ & $36.55( \pm 3.80)^{b c}$ \\
\hline & 50 & $0.31( \pm 0.02)^{b c}$ & $0.15( \pm 0.01)^{\mathrm{abc}}$ & $6.16( \pm 0.66)^{b c}$ & $40.08( \pm 10.01)^{c}$ \\
\hline & 500 & $0.19( \pm 0.02)^{c}$ & $0.08( \pm 0.02)^{\mathrm{ab}}$ & $2.60( \pm 0.99)^{d}$ & $34.94( \pm 9.48)^{c}$ \\
\hline \multirow[t]{3}{*}{8} & Control & $0.49( \pm 0.03)^{a}$ & $0.09( \pm 0.04)^{\mathrm{ab}}$ & $8.03( \pm 1.07)^{a}$ & $57.67( \pm 12.09)^{\mathrm{abc}}$ \\
\hline & 50 & $0.45( \pm 0.02)^{\mathrm{a}}$ & $0.14( \pm 0.02)^{a b c}$ & $7.03( \pm 1.20)^{\mathrm{ab}}$ & $47.76( \pm 7.01)^{\mathrm{abc}}$ \\
\hline & 500 & $0.28( \pm 0.04)^{\mathrm{bc}}$ & $0.14( \pm 0.03)^{\mathrm{abc}}$ & $5.05( \pm 0.93)^{\mathrm{ab}}$ & $51.43( \pm 7.03)^{\mathrm{abc}}$ \\
\hline
\end{tabular}

compared to the $4{ }^{\circ} \mathrm{C}$ treatment but not when compared to $8^{\circ} \mathrm{C}$ (Table 1, Supplementary Table S1).

\section{Photosynthetic pigments}

The variation in pigment composition showed differences with respect to the light and temperature treatments. See Supplementary Table S2 for the results of the statistical analysis (two-way ANOVA, Tukey HSD, $p<0.05)$.

Desmarestia aculeata. The values of chl a tended to decrease at higher light intensity at all temperatures (Fig. la, Supplementary Table S2). Significantly lower values were recorded under the $500 \mu \mathrm{mol}$ photons $\mathrm{m}^{-2} \mathrm{~s}^{-1}$ treatment at all temperatures. Variations due to temperature were not recorded in this species (Fig la, Supplementary Table S2).

The pigments chl $c 2$ and Fuco tend to decrease with high light at all temperatures. Chl $c 2$ values decreased markedly with more light. Significant differences were observed between light treatments for each temperature. No differences were observed between temperatures.
For Fuco, the results showed a tendency to decrease in concentration at higher light and temperature. Significant differences could be observed between light treatments at all temperatures and between the treatment $500 \mu \mathrm{mol}$ photons $\mathrm{m}^{-2} \mathrm{~s}^{-1}$ at $8{ }^{\circ} \mathrm{C}$, with those at $0{ }^{\circ} \mathrm{C}$ and $4{ }^{\circ} \mathrm{C}$ (Fig. lb-c, Supplementary Table S2).

Other pigments in $D$. aculeata such as $\beta$-car, Viol and Anthera showed low concentration values and tended to further decrease with high light. For $\beta$-car, significant differences were observed between the initial control and the $500 \mu \mathrm{mol}$ photons $\mathrm{m}^{-2} \mathrm{~s}^{-1}$ treatment at all temperatures (Fig. ld, Supplementary Table S2). With respect to Viol, the concentration tended to decrease in both light intensities after 21 days of cultivation. Significant differences were observed between treatments of different temperatures. Differences were also observed between the initial control and the $500 \mu \mathrm{mol}$ photons $\mathrm{m}^{-2} \mathrm{~s}^{-1}$ treatment at 4 and $8{ }^{\circ} \mathrm{C}$ (Supplementary Tables S2, S3). For Anthera, differences were only observed at $0{ }^{\circ} \mathrm{C}$ between the initial control treatment with the 50 and $500 \mu \mathrm{mol}$ photons $\mathrm{m}^{-2} \mathrm{~s}^{-1}$ treatments, after 21 days of culture. Finally, significant differences 

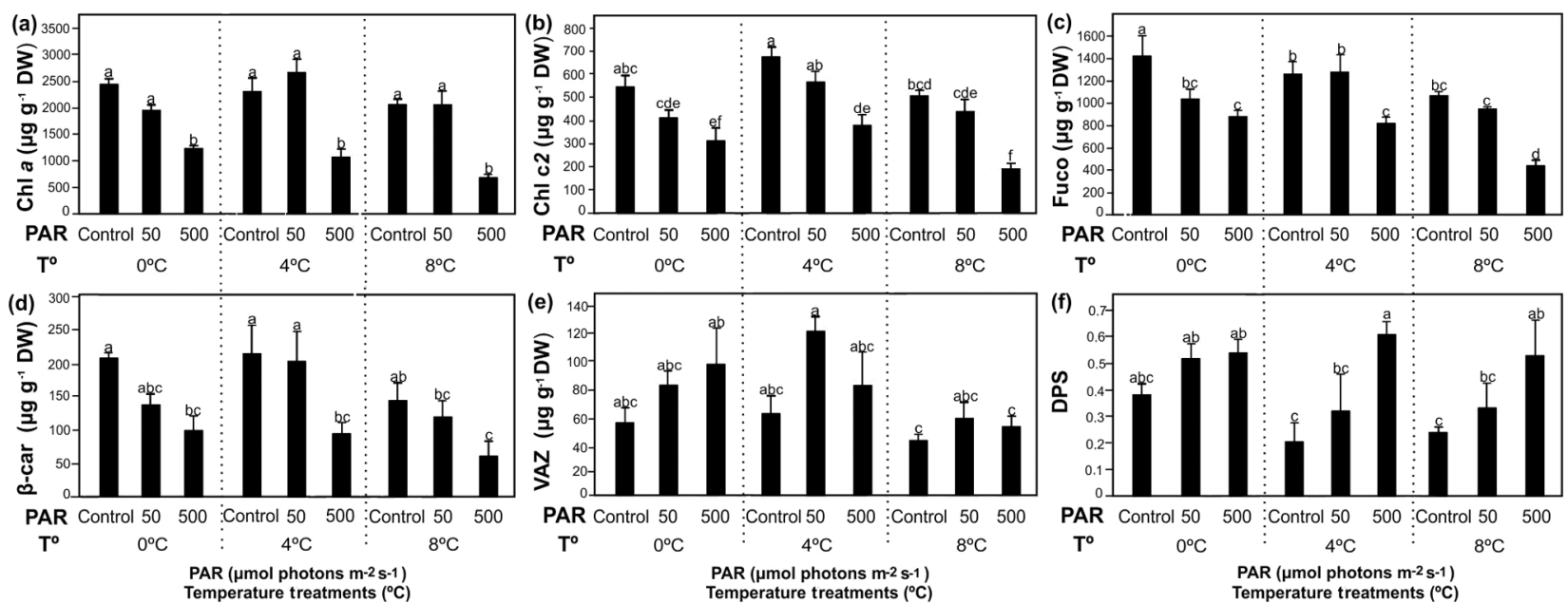

Fig. 1 Mean \pm SD pigment concentrations $(n=3)$ in Desmarestia aculeata. For the pigments chl $a$, chl $c 2$, Fuco, $\beta$-car, the table shows the pool size of the xanthophylls (VAZ) and de-epoxidation status of the xanthophyll cycle (DPS) in ( $\left.\mu \mathrm{g} \mathrm{g}^{-1} \mathrm{DW}\right)$. Samples at three different temperatures $\left(0,4\right.$ and $\left.8^{\circ} \mathrm{C}\right)$ and different light intensities: control (initial control measure $50 \mu \mathrm{mol}$ photons $\mathrm{m}^{-2} \mathrm{~s}^{-1}$ ), 50 and $500 \mu \mathrm{mol}$ photons $\mathrm{m}^{-2} \mathrm{~s}^{-1}$ (after 21 days of culture). Different letters indicate significant differences among light treatments for temperatures $(p<0.05)$

were observed between the initial control treatment at $0{ }^{\circ} \mathrm{C}$ compared with treatments at 4 and $8{ }^{\circ} \mathrm{C}$ (Supplementary Tables S2, S3).

Zeax was present in low concentration, but a tendency for increasing values under high light was identified at all temperatures. Significant differences were observed between the initial control and the $500 \mu \mathrm{mol}$ photons $\mathrm{m}^{-2} \mathrm{~s}^{-1}$ treatment at all temperatures. The temperature factor caused no significant differences in Zeax content (Supplementary Tables S2, S3).

The overall pool size of xanthophyll cycle pigments (VAZ) was low in all treatments, and no major variations were observed between different light intensities, although significant differences were observed between treatments at $8{ }^{\circ} \mathrm{C}$ with 0 and $4{ }^{\circ} \mathrm{C}$ (Fig. le, Supplementary Table S2).

Pigment ratios of $D$. aculeata were calculated from HPLC data (Supplementary Tables S2, S4). The Fuco:chl a pigment ratio tends to show an increase with more light at 4 and $8{ }^{\circ} \mathrm{C}$, but no significant differences were observed. At $0{ }^{\circ} \mathrm{C}$, the initial control showed a significantly higher value compared to the other light treatments. No significant differences were observed between temperatures. The Zeax:chl a ratio presented a trend to increase under $500 \mu \mathrm{mol}$ photons $\mathrm{m}^{-2} \mathrm{~s}^{-1}$ after 21 days of cultivation at all temperatures. However, significant differences were observed only at $8{ }^{\circ} \mathrm{C}$, between specimens under $500 \mu \mathrm{mol}$ photons $\mathrm{m}^{-2} \mathrm{~s}^{-1}$ compared to initial control and specimens under $50 \mu \mathrm{mol}$ photons $\mathrm{m}^{-2} \mathrm{~s}^{-1}$ (Supplementary Tables S2, S4).
The $\beta$-car:chl $a$ and VAZ:chl $a$ ratio did not show significant fluctuations in values, and no significant differences were recorded (Supplementary Tables S2, S4).

The Anthera:chl $a$ ratio tends to increase with high light at all temperatures. However, significant differences were observed at 0 and $4{ }^{\circ} \mathrm{C}$, between the 50 and 500 $\mu \mathrm{mol}$ photons $\mathrm{m}^{-2} \mathrm{~s}^{-1}$ treatments after 21 days of cultivation. Significant differences were also observed between temperatures in some treatments (Supplementary Tables S2, S4). Viol:chl a presented a trend to decrease in value after 21 days of culture at 50 and $500 \mu \mathrm{mol}$ photons $\mathrm{m}^{-2} \mathrm{~s}^{-1}$. In addition, there was a general decrease in values with increasing temperature. Significant differences could be observed between light treatments at $0{ }^{\circ} \mathrm{C}$ and between treatments at 0 and $4{ }^{\circ} \mathrm{C}$.

The ratio chl c2:chl a showed a tendency to increase the values at $500 \mu \mathrm{mol}$ photons $\mathrm{m}^{-2} \mathrm{~s}^{-1}$; however, no significant differences were observed for the light factor, while treatments at different temperatures showed significant differences but not a clear pattern (Supplementary Tables S2, S4).

For DPS, an increase with increasing light intensity was observed at 4 and $8{ }^{\circ} \mathrm{C}$. Significant differences between the initial control and $500 \mu \mathrm{mol}$ photons $\mathrm{m}^{-2} \mathrm{~s}^{-1}$ treatment were recorded at 4 and $8{ }^{\circ} \mathrm{C}$. With respect to the temperature factor, lower values in the initial control treatments at 4 and $8{ }^{\circ} \mathrm{C}$ compared to $0{ }^{\circ} \mathrm{C}$ were recorded, generating significant differences (Fig. If, Supplementary Table S2). The molar ratio ( $\mathrm{chl} c 2+\mathrm{Fuco}) / \mathrm{chl} a$ tended to decrease at 0 and $8{ }^{\circ} \mathrm{C}$ with high light, while at $4{ }^{\circ} \mathrm{C}$, 
values tended to increase. However, no significant differences were observed for the factors light and temperature (Supplementary Tables S2, S4).

Palmaria palmata. Chl a tended to increase with increasing light at all temperatures in comparison to the initial control treatment, but this apparent increase was not significant. In addition, no differences were observed between temperatures, although there was a tendency for the concentration to increase with higher temperatures (Fig. 2a, Supplementary Table S2; two-way ANOVA, Tukey HSD, $p<0.05)$. Lut followed the same trend as chl a, showing an increase in concentration with high light at 0 and $4{ }^{\circ} \mathrm{C}$, but significant differences between light treatments were only observed at $0{ }^{\circ} \mathrm{C}$. Lut concentrations in the initial control and under $50 \mu \mathrm{mol}$ photons $\mathrm{m}^{-2} \mathrm{~s}^{-1}$ at $0{ }^{\circ} \mathrm{C}$ were significantly lower than at higher temperatures (Fig. 2b, Supplementary Table S2). For $\beta$-car, the values tend to decrease at high light at 0 and 8 ${ }^{\circ} \mathrm{C}$, but no significant differences were observed between light treatments. The opposite can be observed between temperatures. This difference was due to an increase in concentration at higher temperature. Significant differences can be observed between treatments at 0 and $8{ }^{\circ} \mathrm{C}$. (Fig. 2c, Supplementary Table S2).

In terms of phycobilin concentration, Pc showed, in general, a lower concentration than Pe, and significant differences in Pc were observed between initial control and $500 \mu \mathrm{mol}$ photons $\mathrm{m}^{-2} \mathrm{~s}^{-1}$ treatments at 4 and $8{ }^{\circ} \mathrm{C}$, tending to decrease in concentration with higher light, whereas temperature was not a factor that affected the treatments. For Pe, an increase in concentration at $500 \mu \mathrm{mol}$ photons $\mathrm{m}^{-2} \mathrm{~s}^{-1}$ treatment was observed at $0{ }^{\circ} \mathrm{C}$.
For temperatures 4 and $8{ }^{\circ} \mathrm{C}$, a decrease in values was observed at high intensity. Significant differences were observed between the initial control and the $500 \mu \mathrm{mol}$ photons $\mathrm{m}^{-2} \mathrm{~s}^{-1}$ treatments for all temperatures (Fig. 2d-e, Supplementary Table S2).

With respect to $\mathrm{Apc}$, at $0{ }^{\circ} \mathrm{C}$, pigment concentration did not show major variations between the different light treatments. For temperatures 4 and $8{ }^{\circ} \mathrm{C}$, pigment concentration decreased towards the $500 \mu \mathrm{mol}$ photons $\mathrm{m}^{-2} \mathrm{~s}^{-1}$ treatment. Significant differences were observed between the initial control treatment and the $500 \mu \mathrm{mol}$ photons $\mathrm{m}^{-2} \mathrm{~s}^{-1}$ treatment for both temperatures. Also, differences were observed between the 50 and $500 \mu \mathrm{mol}$ photons $\mathrm{m}^{-2} \mathrm{~s}^{-1}$ treatments at $4{ }^{\circ} \mathrm{C}$. With respect to the temperature effect, significant differences were observed between treatments, mainly due to a high concentration in the initial control treatment at $8{ }^{\circ} \mathrm{C}$ (Fig. 2f, Supplementary Table S2).

The relative photosynthetic antenna size $(\mathrm{Apc}+\mathrm{Pc}+\mathrm{Pe}) /$ chl $a$ is decreased by high irradiance at 4 and $8{ }^{\circ} \mathrm{C}$ compared to the initial control treatment and at $50 \mu \mathrm{mol}$ photons $\mathrm{m}^{-2} \mathrm{~s}^{-1}$ after 21 days of culture (Supplementary Tables S2, S5). Significant differences were observed between the initial control treatment and the $500 \mu \mathrm{mol}$ photons $\mathrm{m}^{-2} \mathrm{~s}^{-1}$ at 0 and $8{ }^{\circ} \mathrm{C}$. The highest increase in the antennal size was observed at $500 \mu \mathrm{mol}$ photons $\mathrm{m}^{-2} \mathrm{~s}^{-1}$ at $0{ }^{\circ} \mathrm{C}$. The temperature factor showed significant differences between treatments but did not show a clear trend.

The Pc:chl a pigment ratio showed a trend very similar to the antenna size described above. Significant differences were observed between the initial control treatment and
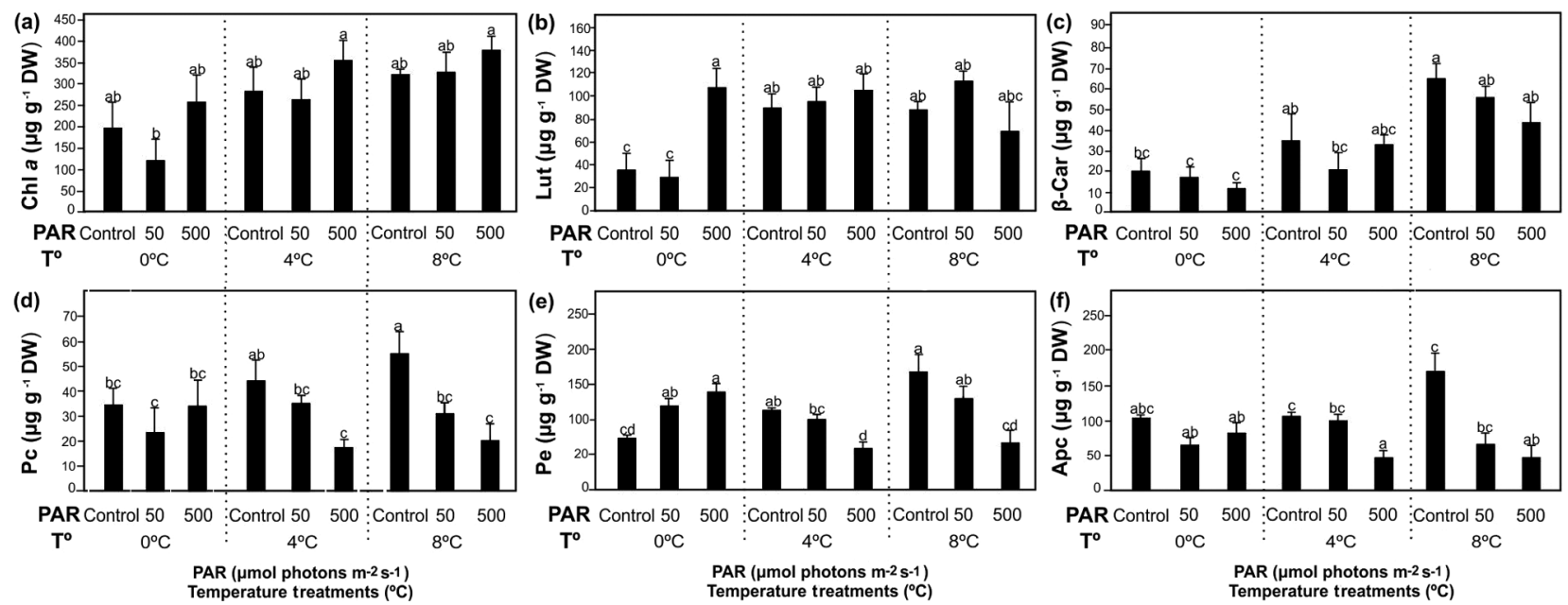

Fig. 2 Mean \pm SD pigment concentration $(n=3)$ in Palmaria palmata. For pigments chl a, Lut, $\beta$-car, Pc, Pe and Apc in ( $\mu g g^{-1}$ DW). Samples at three differ-

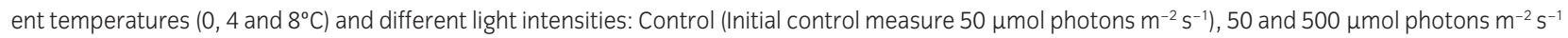
(after 21 days of culture). Different letters indicate significant differences among light treatments for temperatures $(p<0.05)$. 
the $500 \mu \mathrm{mol}$ photons $\mathrm{m}^{-2} \mathrm{~s}^{-1}$ at 0 and $8{ }^{\circ} \mathrm{C}$ (Supplementary Tables S2, S5). The greatest increase in the ratio was observed at $500 \mu \mathrm{mol}$ photons $\mathrm{m}^{-2} \mathrm{~s}^{-1}$ at $0{ }^{\circ} \mathrm{C}$, while at the same light intensity but at 4 and $8{ }^{\circ} \mathrm{C}$, the pigment ratio tended to decrease. The temperature factor caused significant differences between the $500 \mu \mathrm{mol}$ photons $\mathrm{m}^{-2}$ $\mathrm{s}^{-1}$ treatment at 0 and $8{ }^{\circ} \mathrm{C}$; a decrease in the ratio was observed at the highest temperature of $8{ }^{\circ} \mathrm{C}$. The Pe:chl $a$ pigment ratio tended to be influenced by high irradiance after 21 days of culture at $0{ }^{\circ} \mathrm{C}$. While at $8{ }^{\circ} \mathrm{C}$, the values tend to decrease with more light. Significant differences were observed between the initial control and $500 \mu \mathrm{mol}$
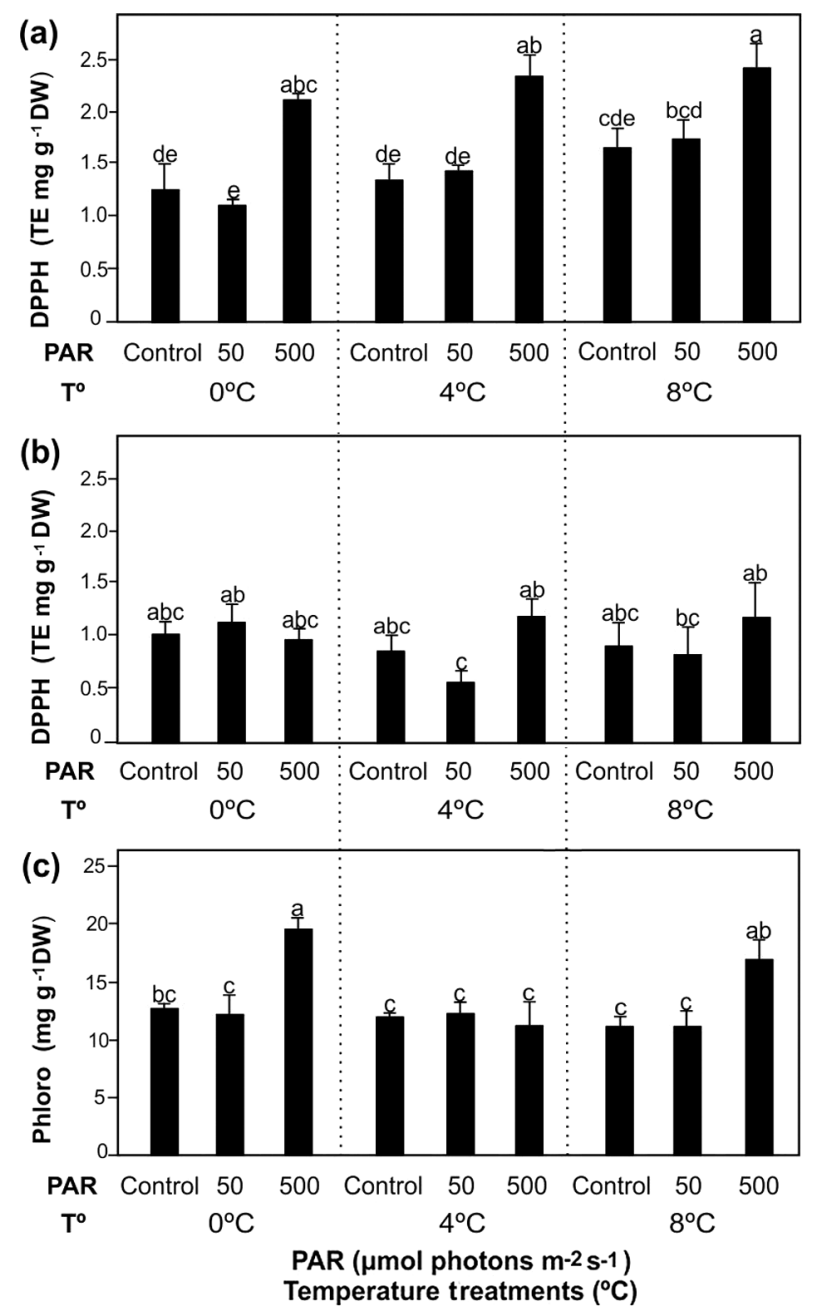

Fig. 3 Antioxidant activity $(n=3)$ is shown for (a) Desmarestia aculeata DPPH (TE mg g ${ }^{-1}$ DW) (b) Palmaria palmata DPPH (TE $\mathrm{mg} \mathrm{g}^{-1}$ DW), and (c) D. aculeata phlorotannins ( $\mathrm{mg} \mathrm{g}^{-1} \mathrm{DW}$ ). Samples at three different temperatures $\left(0,4\right.$ and $\left.8^{\circ} \mathrm{C}\right)$ and different light intensities: control (initial control measure $50 \mu \mathrm{mol}$ photons $\left.\mathrm{m}^{-2} \mathrm{~s}^{-1}\right), 50$ and $500 \mu \mathrm{mol}$ photons $\mathrm{m}^{-2} \mathrm{~s}^{-1}$ (after 21 days of culture). Different letters indicate significant differences among treatments $(p<0.05)$. photons $\mathrm{m}^{-2} \mathrm{~s}^{-1}$ treatment at 0 and $8{ }^{\circ} \mathrm{C}$, while at $4{ }^{\circ} \mathrm{C}$, no differences were observed in the pigment ratio. The temperature factor did not show significant differences between treatments (Supplementary Tables S2, S5). Finally, for the Apc:chl a pigment ratio, an increase in values could be observed for the $500 \mu \mathrm{mol}$ photons $\mathrm{m}^{-2} \mathrm{~s}^{-1}$ treatment at $0{ }^{\circ} \mathrm{C}$. Significant differences were recorded between the initial control and the $500 \mu \mathrm{mol}$ photons $\mathrm{m}^{-2} \mathrm{~s}^{-1}$ treatment. However, the $500 \mu \mathrm{mol}$ photons $\mathrm{m}^{-2} \mathrm{~s}^{-1}$ treatment showed significant differences between temperatures, caused by a decrease in the pigment ratio at higher temperature after 21 days of culture (Supplementary Tables S2, S5).

\section{Antioxidant activity}

The antioxidant activity expressed by the DPPH assay in D. aculeata tends to increase at $500 \mu \mathrm{mol}$ photons $\mathrm{m}^{-2} \mathrm{~s}^{-1}$ at all temperatures. Significant differences between the $500 \mu \mathrm{mol}$ photons $\mathrm{m}^{-2} \mathrm{~s}^{-1}$ and the initial control and the $50 \mu \mathrm{mol}$ photons $\mathrm{m}^{-2} \mathrm{~s}^{-1}$ treatment were recorded. Significant differences were observed for the factors light and temperature (Fig. 3a, Supplementary Table S2; two-way ANOVA, Tukey HSD, $p<0.05)$.

In P. palmata, an increment in the DPPH activity was detected in high light at $500 \mu \mathrm{mol}$ photons $\mathrm{m}^{-2} \mathrm{~s}^{-1}$ at $4{ }^{\circ} \mathrm{C}$ compared to the low light treatment. At 0 and $8{ }^{\circ} \mathrm{C}$ treatments, no major variation in antioxidant activity was observed. Significant differences were observed only for light factor (Fig. 3b, Supplementary Table S2).

Regarding the phlorotannin content in D. aculeata, at 0 and $8{ }^{\circ} \mathrm{C}$, the concentration was higher in the treatment at $500 \mu \mathrm{mol}$ photons $\mathrm{m}^{-2} \mathrm{~s}^{-1}$ after 21 days of cultivation. This was expressed in the presence of significant differences at $500 \mu \mathrm{mol}$ photons $\mathrm{m}^{-2} \mathrm{~s}^{-1}$ compared to the initial control and the $50 \mu \mathrm{mol}$ photons $\mathrm{m}^{-2} \mathrm{~s}^{-1}$ treatment. The temperature factor did not show significant differences between treatments (Fig. 3c, Supplementary Table S2).

\section{Discussion}

The most critical abiotic driver governing macroalgal global distribution is temperature (Lüning 1990), with direct effects on integrative traits like photosynthetic performance, growth and reproduction (Falkowsi \& La Roche 1991). On smaller spatial scales, irradiance is the central but complex abiotic driver controlling the photosynthetic process (Hurd et al. 2014). The composition of the photosynthetic apparatus can be modulated by high irradiance and changes in ambient temperature, and polar macroalgal species are mainly considered to be shade-adapted (Weykam et al. 1996). 
Both species, D. aculeata and P. palmata, with a similar cold-temperate to polar distribution, presented overall similar strategies of ecophysiological acclimation patterns to variation in light and temperature conditions. However, in our experiments, each species showed mixed responses to both increased irradiance and temperature.

\section{Photosynthetic performance}

In general, $D$. aculeata and P. palmata showed similar responses to the experimental variations in irradiance and temperature.

Maximal quantum yield $F_{\mathrm{v}} / F_{\mathrm{m}}$ decreased under high irradiance in both species. The effect of decreased $F_{\mathrm{v}} / F_{\mathrm{m}}$ at high light intensities was also observed in the brown algae Alaria esculenta (Bischof et al. 1999) and in ice algae in Nunavut, Canada (Galindo et al. 2017). It is known that high irradiance may cause photoinhibition in macroalgae, particularly in species inhabiting deeper waters (Hanelt 1998; Karsten et al. 2001), such as D. aculeata in the subtidal zone. However, $P$. palmata showed a tendency to increase its $F_{\mathrm{v}} / F_{\mathrm{m}}$ values with increasing temperature. The opposite was registered by Gordillo et al. (2016), who observed an overall negative effect of temperature increase on $F_{\mathrm{v}} / F_{\mathrm{m}}$ in different macroalgal lineages in the Arctic. The reversible reduction in maximal quantum yield was characterized by Osmond (1994) as 'dynamic photoinhibition', a strategy to protect photosynthetic reaction centres from the excess light absorbed, and thus to suppress the generation of reactive oxygen. Persistently, low values of $F_{\mathrm{v}} / F_{\mathrm{m}}$ in treatments with high irradiance indicate, according to observations by Lüder et al. (2002), damage to the PSII reaction centre. Dynamic photoinhibition is described as a common strategy of protection against high irradiance in algae inhabiting the intertidal zone (Becker et al. 2009).

Both species studied presented a trend to decrease in rETRmax values at increasing irradiances and in some temperature treatments. However, in long-term studies, for example, comparing seasonal patterns, the opposite trend is usually observed. Bischof et al. (2002) described that for brown macroalgae in Kongsfjorden, how the photosynthetic variables vary according to the presence of sea-ice cover and underwater light availability. Species such as D. aculeata and Saccharina latissima show an increase in rETRmax values during the months of highest underwater irradiance and absence of sea ice. For P. palmata, Hanelt et al. (2003) conducted studies in the Kongsfjorden area and reported increasing rETRmax at higher temperature. Although temperature was not a decisive factor in this parameter, specific differences were observed in the high light treatment between $8{ }^{\circ} \mathrm{C}$ and the other temperatures. Hence, light is suggested to be the predominant factor in generating stress in the species P. palmata. Hanelt et al. (2003) described habitat-specific light-acclimation in P. palmata, which might become saturated with light above $100 \mu \mathrm{mol} \mathrm{m} \mathrm{m}^{-2} \mathrm{~s}^{-1}$. However, in our study, there was a decrease in rETRmax at high irradiances, and values generally increased at higher temperatures, which could be attributed to a more efficient drain of reduction equivalents consumed in the Calvin cycle at moderately increased temperatures.

The reduced photosynthetic activity observed in both species during our experiments seems to be a sign of efficient regulatory processes that buffer against rapid and sudden variations in environmental factors and ultimately minimize oxidative stress (ROS). The opposite trend of increasing photosynthetic performance with irradiance was observed in seasonal studies, reflecting acclimation processes to a changing light environment over weeks to months (Aguilera et al. 2002; Bischof et al. 2002).

The initial slopes of the P-E curves (i.e., $\alpha$ values) in $D$. aculeata and P. palmata showed a similar pattern: decreasing $\alpha$ in the presence of high irradiance at $0{ }^{\circ} \mathrm{C}$. Neither species showed significant effects of temperature for this parameter. This response shows that the two species are similarly able to adapt to individual changes in environmental factors.

In both $D$. aculeata and P. palmata, the parameter Ek tended to decrease in the presence of high irradiance. High irradiance strongly affects $D$. aculeata, which is explained by its characteristic as a subtidal species. Photosynthesis in species from deeper waters is more prone to inhibition in the presence of high irradiance and may take longer to recover (Hanelt 1998; Karsten et al. 2001). Although, in general, light was not the deciding factor for P. palmata, temperature made a difference. A different pattern was observed by Sagert \& Schubert (2000), who observed an increase in $E \mathrm{k}$ values with increasing light intensity for $P$. palmata. The inconsistency between our results and those of Sagert \& Schubert may lie in the limited duration of our experiment, which may not have been long enough to achieve acclimation to increased irradiances. On the other hand, low Ek values are a sign of the adaptation to darkness or general light-limitation, as is characteristic for polar algae (Wiencke et al. 2006).

\section{Photosynthetic pigments}

Becker et al. (2009) mention that a decrease in temperature, combined with an increase in PAR, is a severe stressor for algae, resulting in the inhibition of photosynthetic performance and alterations in pigment content. Both species studied presented different responses with respect to the combination of abiotic drivers, which 
was also reflected by pigment composition changes in the two species.

The species $D$. aculeata presented a decrease in overall pigment concentration, mainly in chl $a$, chl $c 2$, Fuco and $\beta$-car, mainly in response to increasing irradiance; for Fuco and $\beta$-car, temperature was an additional driver. It is well established that this type of physiological adjustment is a key in the process of photo-acclimation under high irradiance (Hurd et al. 2014). In particular, light harvesting is reduced to avoid overexcitation, ROS production and chronic photoinhibition. In seasonal studies of Laminaria digitata and S. latissima, it has been observed that, like in D. aculeata, the high irradiance and the increase in temperature during the summer months influence pigment concentration, which has been reported as acclimation to seasonal changes (Hallerud 2014).

The VAZ pigments participated in the xanthophyll cycle were generally present at low concentrations. The low concentration of these pigments in polar seaweed was also recorded by Hallerud (2014). However, in our study, all three pigments responded to increasing irradiance as the most driving factor. For example, Zeax showed an increase at higher irradiance in all temperatures in $D$. aculeata, this being a short-term regulatory response. Heriyanto et al. (2017) recorded for brown algae that Zeax increases as a consequence of de-epoxidation of Viol in response to high light intensities. This result is further reflected in $D$. aculeata by the increasing trend in the pigment ratio of Fuco:chl $a$ and Zeax:chl $a$ at high light. Overall, our data show that this species is sensitive to high irradiance, as reflected in the ratios Anthera:chl $a$ and Viol:chl $a$. Our experiments also showed that responses to increasing temperature for parameters such as Anthera:chl $a$ and Viol:chl $a$ are negatively affected, while chl c2:chl a did not show a clear pattern with respect to temperature.

These findings are consistent with laboratory and field studies carried out by Chapman \& Burrows (1970), who showed that light is more important than temperature for the development and growth of $D$. aculeata. On the other hand, pigment ratios, such as $\beta$-car:chl $a$ and VAZ:chl $a$, and molar ratios were not affected by light or temperature for $D$. aculeata in our study. The trend of increasing pool size of the xanthophyll cycle (VAZ) in the face of high irradiances at 0 and $4{ }^{\circ} \mathrm{C}$ reinforces the idea that the light sensitivity of $D$. aculeata is key to its physiology, and that temperature might be a secondary factor, generating the decrease of VAZ. At the same time, we found an increase in DPS in the presence of high irradiances. The increase in VAZ and DPS is part of the process of photoprotection against oxidative stress (Olischläger et al. 2017; Li et al. 2019). For D. aculeata, data suggest a strong capacity to acclimate to environmental variables, with light and temperature being the triggers of physiological adjustments. In our study, D. aculeata presented higher values at $0{ }^{\circ} \mathrm{C}$ compared to the higher temperatures, in agreement with observations by Bischof et al. (2002), who found that decreases in temperature have modulating effects on these processes.

In P. palmata, high concentrations of chl $a$ were maintained in all treatments. However, seasonal studies of $P$. palmata showed an increase in chl a concentration during the spring months and a subsequent decrease in response to high irradiance during the summer months (Hallerud 2014; Lalegerie et al. 2020). Although our study shows the response over a limited period of time, it indicates well the acclimation capacity of P. palmata. However, it is to be expected that increasing irradiance beyond a certain threshold would result in a loss of chl $a$, to avoid photodamage and photoinhibition, as described by Raven $\delta$ Hurd (2012).

This notion is supported by the increase of $\beta$-car to high temperature, and the Lut increment at high irradiance and low temperature observed in this study. However, some studies suggest that in P. palmata specimens, in France, carotenoids, in general, function as accessory pigments in light-harvesting and not as a mechanism of photoprotection (Hashimoto et al. 2016: Lalegerie et al. 2020). Still, we suggest that for P. palmata at High-Arctic latitudes, carotenoids could have an important role contributing to the mechanisms of photoprotection, particularly in a high irradiance/low temperature environment. This trend was also observed by Hallerud (2014) during a seasonal study of $P$. palmata.

With respect to the red algal pigments, none of the phycobilliproteins showed large differences at low temperatures, but they decreased in concentration at high irradiance. Aguilera et al. (2002) described that P. palmata decreases in Pe and Pc under high irradiance. The increase in the antenna size and pigment ratios Pe:chl $a$, Pc:chl $a$ and Apc:chl $a$ at high irradiance was observed at low temperatures, while the opposite trend was observed with higher temperatures, suggesting the combined effect of both factors in P. palmata.

Both species tended to have a combined response to irradiance and temperature variation. Desmarestia aculeata commonly inhabits the subtidal zone, but it is also observed shallower areas. Palmaria palmata inhabits the intertidal zone, a habitat characterized by great variation in environmental drivers, and is, therefore, expected to be more adapted to tolerating significant increases in irradiance.

\section{Antioxidative activity}

A number of macroalgae have the capacity to produce phlorotannins as a general response to different types of 
environmental stress, allowing a general but fast adaptive response (Springer et al. 2017). The concentration of phlorotannins in $D$. aculeata was influenced by high irradiance. It is possible that in $D$. aculeata, phlorotannins are mainly found as cell wall compounds, playing a phytoprotective role with respect to environmental variations such as PAR light. However, phlorotannins have several secondary functions, such as UV defence and warding off herbivores (Koivikko et al. 2005; Abdala et al. 2006; Koch et al. 2015).

In D. aculeata, we observed an increase in antioxidant activity at higher irradiances and influenced by high temperature. In this case, the antioxidant activity has an important photoprotective function. In contrast, the antioxidant activity of P. palmata is influenced mainly at high irradiances. A similar situation occurs with mycosporins in P. palmata; Yuan et al. (2009) observed an increase in mycosporin in high UV light.

In response to both environmental factors, $D$. aculeata might be characterized as an alga with moderate acclimation capacity, while P. palmata presents a more pronounced light acclimation capacity and is not strongly affected by temperature.

\section{Ecological implications}

The Arctic is currently experiencing a number of rapid environmental changes. He et al. (2019) describe how the decrease in sea-ice cover has led to increased absorption of irradiance into the water column due to its darker surface. Hence, the reduction of sea ice will lead to a further increase in ocean temperature (Higgins \& Cassano 2009). In parallel, seaweed communities are constantly changing, and their responses to climate change are fundamental to understanding the current and future coastal ecosystems in the High Arctic (Bartsch et al. 2016; Bischof et al. 2019). Arctic species are increasingly exposed to high irradiances for longer periods of time, in addition to rising temperatures and other variations in environmental variables (Lüning 1990; Filbee-Dexter et al. 2019). Species originating in lower latitudes, such as $D$. aculeata and P. palmata, have managed to adapt to Arctic conditions; however, they have maintained their adaptive traits for temperate conditions. Both species studied share similar features with respect to geographic distribution and temperature requirements (Lüning 1990). However, P. palmata is more tolerant to high temperatures and usually populates a higher shore level than D. aculeata. This difference in depth distribution clearly matches the ecophysiological responses observed during this work. Our study demonstrates how Arctic isolates of these two species, which belong to different algal classes and show similar acclimation responses to variations in environmental factors, which are, however, based on different biochemical processes. With its higher sensitivity to temperature and irradiance changes, $D$. aculeata might be more affected by increasingly ice-free areas. High light exposure could be counteracted, however, by an increased release of turbid meltwater in coastal areas, reducing light availability. In contrast, it is likely that $P$. palmata will soon become much more abundant in fjord systems throughout the Arctic on the account of its relative resistance to temperature increases, as diminishing sea ice will offer the species greater opportunities to populate the shallow subtidal zone.

\section{Acknowledgements}

The authors are thankful to the AWIPEV Base in Ny-Ålesund, which hosted us, and for the logistical support provided by the Alfred Wegener Institute and its diving team.

\section{Disclosure statement}

The authors report no conflict of interest.

\section{Funding}

The Alfred Wegener Institute provided the financial support. JM is grateful for the National Agency for Research and Development (ANID)/Scholarship Program Becas Chile - DAAD/DOCTORADO BECAS CHILE/2017 72180000 . In addition, this project received funding from the European Union's Horizon 2020 research and innovation programme under grant agreement no. 869154 .

\section{References}

Abdala R.T., Cabello A., Pérez E., Conde R.M. \& Figueroa F.L. 2006. Daily and seasonal variations of optimum quantum yield and phenolic compounds in Cystoseira tamariscifolia (Phaeophyta). Marine Biology 148, 459-465, doi: 10.1007/ s00227005-0102-6.

Aguilera J., Bischof K., Karsten U., Hanelt D. \& Wiencke C. 2002. Seasonal variation in ecophysiological patterns in macroalgae from an Arctic fjord. II. Pigment accumulation and biochemical defence systems against high light stress. Marine Biology 140, 1087-1095, doi: 10.1007/ s00227-002-0792-y.

Aro E.M., Virgin I. \& Andersson B. 1993. Photoinhibition of Photosystem II. Inactivation, protein damage and turnover. Biochimica et Biophysica Acta 1143, 113-134, doi: 10.1016/0005-2728(93)90134-2.

Bartsch I., Paar M., Fredriksen S., Schwanitz M., Daniel C., Hop H. \& Wiencke C. 2016. Changes in kelp forest biomass and depth distribution in Kongsfjorden, Svalbard, between 
1996-1998 and 2012-2014 reflect Arctic warming. Polar Biology 39, 2021-2036, doi: 10.1007/s00300-015-1870-1.

Becker S., Walter B. \& Bischof K. 2009. Freezing tolerance and photosynthetic performance of polar seaweeds at low temperatures. Botanica Marina 52, 609-616, doi: 10.1515/ BOT.2009.079.

Bischof K., Convey P., Duarte P., Gattuso J.P., Granberg M., Hop H., Hoppe C., Jiménez C., Lisitsyn L., Martinez B., Roleda M.Y., Thor P., Wiktor J.M. \& Gabrielsen G.W. 2019. Kongsfjorden as harbinger of the future Arctic: knowns, unknowns and research priorities. In H. Hop \& C. Wiencke (eds.): The ecosystem of Kongsfjorden, Svalbard. Pp 537-562. Cham, Switzerland: Springer.

Bischof K., Hanelt D., Aguilera J., Karsten U., Vögele B., Sawall T. \& Wiencke C. 2002. Seasonal variation in ecophysiological patterns in macroalgae from an Arctic fjord. I. Sensitivity of photosynthesis to ultraviolet radiation. Marine Biology 140, 1097-1106, doi: 10.1007/ s00227-002-0795-8.

Bischof K., Hanelt D. \& Wiencke C. 1999. Acclimation of maximal quantum yield of photosynthesis in the brown alga Alaria esculenta und high light and UV radiation. Plant Biology 1, 435-444, doi: 10.1111/j.1438-8677.1999.tb00726.x.

Bjarnadóttir M., Aðalbjörnsson B.V., Nilsson A., Slizyte R., Roleda M.Y., Hreggviðsson G.Ó., Friðjónsson O.H. E Jónsdóttir R. 2018. Palmaria palmata as an alternative protein source: enzymatic protein extraction, amino acid composition, and nitrogen-to-protein conversion factor. Journal of Applied Phycology 30, 2061-2070, doi: 10.1007/ s10811-017-1351-8.

Brand-Williams W., Cuvelier M.E. \& Berset C. 1995. Use of a free radical method to evaluate antioxidant activity. LWT Food Science and Technology 28, 25-30, doi: 10.1016/ S0023-6438(95)80008-5.

Bringloe B., Verbruggenb H., \& Saundersa G.W. 2020. Unique biodiversity in Arctic marine forests is shaped by diverse recolonization pathways and far northern glacial refugia. Proceedings of the National Academy of Science of the United States of America 117, 22590-22596, doi: 10.1073/ pnas.2002753117.

Chapman A.R.O. \& Burrows E.M. 1970. Experimental investigations into the controlling effects of light conditions on the development and growth of Desmarestia aculeata (L.) Lamour. Phycology 9, 103-108, doi: 10.2216/ i0031-8884-9-1-103.1.

Colombo-Pallotta M., García E. \& Ladah L. 2006. Photosynthetic performance, light absorption, and pigment composition of Macrocystis pyrifera (Laminariales, Phaeophyceae) blades from different depths. Journal of Phycology 42, 12251234, doi: 10.1111/j.1529-8817.2006.00287.x.

Cruces E., Huovinen P. \& Gómez I. 2012. Phlorotannin and antioxidant responses upon short-term exposure to UV radiation and elevated temperature in three South Pacific kelps. Photochemistry and Photobiology 88, 58-66, doi: $10.1111 / \mathrm{j} .1751-1097.2011 .01013 . x$.

Diehl N., Karsten U. \& Bischof K. 2020. Impacts of combined temperature and salinity stress on the endemic Arctic brown seaweed Laminaria solidungula J. Agardh. Polar Biology 43, 647-656, doi: 10.1007/s00300-020-02668-5.
Dunton K.H. \& Dayton P.K. 1995. The biology of high latitude kelp. In H.R. Skjoldal et al. (eds.): Ecology of fjords and coastal waters. Pp. 499-507. Amsterdam: Elsevier.

Falkowsi P. \& La Roche J. 1991. Acclimation to spectral irradiance in algae. Journal of Phycology 27, 8-14, doi: $10.1111 /$ j.0022-3646.1991.00008.x.

Filbee-Dexter K., Wernberg T., Fredriksen S., Norderhaug K.M. \& Pedersen M.F. 2019. Arctic kelp forests: diversity, resilience and future. Global and Planetary Change 172, 1-14, doi: 10.1016/j.gloplacha.2018.09.005.

Francis J.A. \& Hunter E. 2006. New insight into the disappearing Arctic sea ice. Eos, Transactions American Geophysical Union 87, 509-524, doi: 10.1029/2006EO460001.

Fredriksen S., Karsten U., Bartsch I., Woelfel J., Koblowsky M., Schumann R., Moy S.R., Steneck R.S., Wiktor J.M., Hop H. \& Wiencke C. 2019. Biodiversity of benthic macroand microalgae from Svalbard with special focus on Kongsfjorden. In H. Hop \& C. Wiencke (eds.): The ecosystem of Kongsfjorden, Svalbard. Pp. 331-371. Cham, Switzerland: Springer.

Galindo V., Gosselin M., Lavaud J., Mundy C.J., Else B., Ehn J., Babin M. \& Rysgaard S. 2017. Pigment composition and photoprotection of Arctic sea ice algae during spring. Marine Ecology Progress Series 585, 49-69, doi: 10.3354/meps 1239.

Gordillo F., Carmona R., Viñegla V., Wiencke C. \& Jimenez C. 2016. Effects of simultaneous increase in temperature and ocean acidification on biochemical composition and photosynthetic performance of common macroalgae from Kongsfjorden (Svalbard). Polar Biology 39, 1993-2007, doi: 10.1007/s00300-016-1897-y.

Hallerud C.B. 2014. Pigment composition of macroalgae from a Norwegian kelp forest. MSc thesis, Dept. of Biology, Norwegian University of Science and Technology.

Hanelt D. 1998. Capability of dynamic photoinhibition in Arctic macroalgae is related to their depth distribution. Marine Biology 131, 361-369, doi: 10.1007/s002270050329.

Hanelt D. \& Nultsch W. 1995. Field studies of photoinhibition show non-correlations between oxygen and fluorescence measurements in the Arctic red alga Palmaria palmata. Journal of Plant Physiology 145, 31-38, doi: 10.1016/ S0176-1617(11)81842-0.

Hanelt D., Tüg H., Bischof K., Groß C., Lippert H., Sawall T. \& Wiencke C. 2001. Light regime in an Arctic fjord: a study related to stratospheric ozone depletion as a basis for determination of UV effects on algal growth. Marine Biology 138, 649-658, doi: 10.1007/s002270000481.

Hanelt D., Wiencke C. \& Bischof K. 2003. Photosynthesis in marine macroalgae. In W.A. Larkum et al. (eds.): Photosynthesis in algae. Vol. 14. Pp. 413-435. Dordrecht, the Netherlands: Kluwer Academic Publishers.

Hashimoto H., Uragami C. \& Cogdell R.J. 2016. Carotenoids and photosynthesis. In C. Stange (ed.): Carotenoids in nature: biosynthesis, regulation and function. Pp. 111-139. Cham, Switzerland: Springer.

He M., Hu Y., Chen N., Wang D., Huang J. \& Stamnes K. 2019. High cloud coverage over melted areas dominates the impact of clouds on the albedo feedback in the Arctic. Scientific Reports 9, article no. 9529, doi: 10.1038/ s41598-019-44155-w. 
Heriyanto H., Juliadiningtyas A.D., Shioi Y., Limantara L. \& Brotosudarmo T.H.P. 2017. Analysis of pigment composition of brown seaweeds collected from Panjang Island, central Java, Indonesia. Philippine Journal of Science 146, 323-330.

Higgins M.E. \& Cassano J.J. 2009. Impacts of reduced sea ice on winter Arctic atmospheric circulation, precipitation, and temperature. Journal of Geophysical Research-Atmospheres 114, D16107, doi: 10.1029/2009JD01 1884.

Holzinger A., Lütz C., Karsten U., \& Wiencke C. 2004. The effect of ultraviolet radiation on ultrastructure and photosynthesis in the red macroalgae Palmaria palmata and Odonthalia dentata from Arctic waters. Plant Biology 6, 568577, doi: 10.1055/s-2004-821003.

Hop H., Pearson T., Hegseth E.N., Kovacs K.M., Wiencke C., Kwasniewski S., Eiane K, Mehlum F., Gulliksen B., Kowalczuk M.W., Lydersen C., Weslawski J.M., Cochrane S., Gabrielsen G.W., Leakey R., Lönne O.J., Zajaczkowski M., Petersen S.F., Kendall M., Wängberg S.A., Bischof K., Voronkov Y., Kovaltchouk N.A., Wiktor J., Poltermann M., Prisco G., Papucci C. \& Gerland S. 2002. The marine ecosystem of Kongsfjorden, Svalbard. Polar Research 21, 167-208, doi: 10.3402/polar.v2 li1.6480.

Hurd C.L., Harrison P.J., Bishof K. \& Lobban C.S. (eds.) 2014. Seaweed ecology and physiology. Cambridge: Cambridge University Press.

Iñiguez C., Carmona R., Lorenzo M.R., Niell F.X., Wiencke C. \& Gordillo F.J.L. 2015. Increased $\mathrm{CO}_{2}$ modifies the carbon balance and the photosynthetic yield of two common Arctic brown seaweeds: Desmarestia aculeata and Alaria esculenta. Polar Biology 39, 1979-1991, doi: 10.1007/ s00300-015-1724-x.

Kain J. \& Jones S. 1975. Algal recolonization of some cleared subtidal areas. Journal of Ecology 63, 739-765, doi: $10.2307 / 2258599$.

Karsten U., Bischof K. \& Wiencke C. 2001. Photosynthetic performance of Arctic macroalgae after transplantation from deep to shallow waters followed by exposure to natural solar radiation. Oecologia 127, 11-20, doi: 10.1007/ s004420000553.

Karsten U., Dummermuth A., Hoyer K. \& Wiencke C. 2003. Interactive effects of ultraviolet radiation and salinity on the ecophysiology of two Arctic red algae from shallow waters. Polar Biology 26, 249-258, doi: 10.1007/s00300-002-0462-z.

Karsten U. \& Wiencke C. 1999. Factors controlling the formation of UV-absorbing mycosporine-like amino acids in the marine red alga Palmaria palmata from Spitsbergen (Norway). Journal of Plant Physiology 155, 407-415, doi: 10.1016/S0176-1617 (99) 80124-2.

Koch K., Thiel M., Hagen W., Graeve M., Gómez I., Jofre D., Hoffman L., Tala F. \& Bischof K. 2016. Short- and longterm acclimation patterns of the giant kelp Macrocystis pyrifera (Laminariales, Phaeophyceae) along a depth gradient. Journal of Phycology 52, 260-273, doi: 10.1111 /jpy.12394.

Koch K., Thiel M., Tellier F., Hagen W., Graeve M., Tala F., Laesecke P. \& Bischof K. 2015. Species separation within the Lessonia nigrescens complex (Phaeophyceae, Laminariales) is mirrored by ecophysiological traits. Botanica Marina 58, 81-92, doi: 10.1515/bot-2014-0086.
Koivikko R., Loponen J., Honkanen T. \& Jormalainen V. 2005. Contents of soluble, cell-wall-bound and exuded phlorotannins in the brown alga Fucus vesiculosus, with implications on their ecological aspects. Journal of Chemical Ecology 31, 195-212, doi: 10.1007/s10886-005-0984-2.

Krause-Jensen D., Duarte C.M., Hendriks I.E., Meire L., Blicher M.E., Marbà N. \& Sejr M.K. 2015. Macroalgae contribute to nested mosaics of $\mathrm{pH}$ variability in a Subarctic fjord. Biogeosciences 12, 4895-4911, doi: 10.5194/ bg-12-4895-2015.

Kursar T.A., Van der Meer J.P. \& Aberte R.S. 1983. Light harvesting system of the red alga Gracilaria tikvahiae. I. Biochemical analyses of pigment mutations. Plant Physiology 73, 353-360, doi: 10.1104/pp.73.2.353

Lahaye M., Michel C. \& Barry J.L. 1993. Chemical, physicochemical and in-vitro fermentation characteristics of dietary fibres from Palmaria palmata (L.) Kuntze. Food Chemistry 47, 29-36, doi: 10.1016/0308-8146(93)90298-T.

Lalegerie F., Stiger-Pouvreau V. \& Connan S. 2020. Temporal variation in pigment and mycosporine-like amino acid composition of the red macroalga Palmaria palmata from Brittany (France): hypothesis on the MAA biosynthesis pathway under high irradiance. Journal of Applied Phycology 32, 2641-2656, doi: 10.1007/s10811-020-02075-7.

Lee D., Nishizawa M., Shimizu Y. \& Saeki H. 2017. Anti-inflammatory effects of dulse (Palmaria palmata) resulting from the simultaneous water-extraction of phycobiliproteins and chlorophyll a. Food Research International 100, 514-521, doi: 10.1016/j.foodres.2017.06.040.

Le Gall L., Pien S. \& Rusig A.M. 2004. Cultivation of Palmaria palmata (Palmariales, Rhodophyta) from isolated spores in semi-controlled conditions. Aquaculture 229, 181-191, doi: 10.1016/S0044-8486 (03) 00390-9.

Li H., Monteiro C., Heinrich S., Bartsch I., Valentin K., Harms L., Glöckner G., Corre E. \& Bischof K. 2019. Responses of the kelp Saccharina latissima (Phaeophyceae) to the warming Arctic: from physiology to transcriptomics. Physiologia Plantarum 168, 5-26, doi: 10.1111/ppl.13009.

Lippert H., Iken K., Rachor E. \& Wiencke C. 2001. Macrofauna associated with macroalgae in the Kongsfjord (Spitsbergen). Polar Biology 24, 512-522, doi: 10.1007/ s003000100250.

Lüder U.H., Wiencke C. \& Knoetzel J. 2002. Acclimation of photosynthesis and pigments during and after six months of darkness in Palmaria decipiens (Rhodophyta): a study to stimulate Antarctic winter sea ice cover. Journal of Phycology 38, 904-913, doi: 10.1046/j.1529-8817.2002. t01-1-01071.x.

Lüning K. (ed.) 1990. Seaweeds: their environment, biogeography, and ecophysiology. New York: Wiley.

MacArtain P., Gill C.I.R., Brooks M., Campbell R. \& Rowland I.R. 2007. Nutritional value of edible seaweeds. Nutritional Reviews 65, 535-543, doi: 10.1301/nr.2007.dec.535-543.

Mathieson A.C. \& Dawes C.J. (eds.) 2017. Seaweeds of the northwest Atlantic. Amherst: University of Massachusetts Press.

Miller G.H., Brigham-Grette J., Anderson L., Henning B., Douglas M. A., Edwards M.E., Elias S., Finney B., Funder S., Herbert T., Hinzman L., Kaufman D. K., MacDonald G., 
Robock A., Serreze M., Smol J., Spielhagen R., Wolfe A.P. \& Wolff E. 2009. Temperature and precipitation history of the Arctic. In Alley R.B. et al. (eds.): Past climate variability and change in the Arctic and at high latitudes. Pp. 77-246. Washington, DC: US Climate Change Science Program.

Müller R., Wiencke C. \& Bischof K. 2008. Interactive effects of UV radiation and temperature on microstages of Laminariales (Paheophyceae) from the Arctic and North Sea. Climate Research 37, 203-213, doi: 10.3354/cr00762.

Nielsen R. \& Lundsteen S. 2019. Danmarks havalger. Bind 2. Brunalger (Phaeophyceae) og gronalger (Chlorophyta). (Denmark's sea algae. Vol. 2. Brown algae [Phaeophyceae] and green algae [Chlorophyta].) Scientia Danica. Series B, Biologica 8. Copenhagen: The Royal Danish Academy of Sciences and Letters.

Olischläger M., Iñiguez C., Koch K., Wiencke C. \& Gordillo F.J.L. 2017. Increases in $\mathrm{pCO}_{2}$ and temperature reveal ecotypic differences in growth and photosynthetic yield of temperate and Arctic Saccharina latissima. Planta 245, 119-136, doi: 10.1007/s00425-016-2594-3.

Osmond C.B. 1994. What is photoinhibition? Some insights from comparisons of shade and sun plants. In N.R. Baker \& J.R. Bowyer (eds.): Photoinhibition of photosynthesis. From the molecular mechanisms to the field. Pp. 1-24. Oxford: BIOS Scientific Publications.

Pehlke C. \& Bartsch I. 2008. Changes in depth distribution and biomass of sublittoral seaweeds at Helgoland (North Sea) between 1970 and 2005. Climate Research 37, 135-147, doi: $10.3354 / \mathrm{cr} 00767$.

Platt T., Gallegos C.L. \& Harrison W.G. 1980. Photoinhibition of photosynthesis in natural assemblages of marine phytoplankton. Journal Marine Research 38, 687-701.

Raven J.A. \& Hurd C.L. 2012. Ecophysiology of photosynthesis in macroalgae. Photosynthesis Research 113, 105-125, doi: 10.1007/s11120-012-9768-z.

Sagert S. \& Schubert H. 2000. Acclimation of Palmaria palmata (Rhodophyta) to light intensity: comparison between artificial and natural light fields. Journal of Phycology 36, 1119-1128, doi: 10.1046/j.1529-8817.2000.99156.x.

Schreiber U., Bilger W. \& Neubauer C. 1995. Chlorophyll fluorescence as a non-intrusive indicator for rapid assessment of in vivo photosynthesis. In E.D. Schulze \& M.M. Caldwell (eds.): Ecophysiology of photosynthesis. Vol. 100. Pp. 49-70. Berlin: Springer.

Serreze M.C. \& Francis J.A. 2006. The Arctic amplification debate. Climatic Change 76, 241-264, doi: 10.1007/ s10584-005-9017-y.

Springer K., Lütz C., Lütz-Meindl U., Wendt A. \& Bischof K. 2017. Hyposaline conditions affect UV susceptibility in the Arctic kelp Alaria esculenta (Phaeophyceae)—results of laboratory experiments at Kongsfjorden. Phycologia 56, 675-685, doi: 10.2216/16-122.1.
Van De Poll W., Eggert A., Buma A. \& Breeman A. 2002. Temperature dependence of UV radiation effects in Arctic and temperate isolates of three red macrophytes. European Journal of Phycology 37, 59-68, doi: 10.1017/ S0967026201003407.

Wang T., Jónsdóttir R., Kristinsson H.G., Hreggvidsson G.O., Jónsson J.Ó., Thorkelsson G. \& Ólafsdóttir G. 2010. Enzyme-enhanced extraction of antioxidant ingredients from red alga Palmaria palmata. LWT Food Science and Technology 43, 1387-1393, doi: 10.1016/j.lwt.2010. 05.010 .

Weykam G., Gómez I., Wiencke C., Iken K. \& Klöser H. 1996. Photosynthetic characteristics and C:N ratios of macroalgae from King George Island (Antarctica). Journal of Experimental Marine Biology and Ecology 204, 1-22, doi: 10.1016/0022-0981(96)02576-2

Wiencke C. \& Amsler C. 2012. Seaweeds and their communities in polar regions. In C. Wiencke $\&$ K. Bischof (eds.): Seaweed biology. Novel insights into ecophysiology, ecology and utilization. Pp. 265-291. Berlin: Springer.

Wiencke C., Clayton M.N., Goméz I., Iken K., Lüder U.H., Amsler C.D., Karsten U., Hanelt D., Bischof K. \& Dunton K. 2006. Life strategy, ecophysiology and ecology of algae in polar waters. Reviews in Environmental Science and Biotechnology 6, 95-126, doi: 10.1007/s11157-0069106-z.

Wiencke C., Gómez I. \& Dunton K. 2011. Phenology and seasonal physiological performance of polar seaweeds. In C. Wiencke (ed.): Biology of polar benthic algae. Pp. 181-194. Berlin: De Gruyter.

Wiencke C. \& Hop H. 2016. Ecosystem Kongsfjorden: new views after more than a decade of research. Polar Biology 39, 1679-1687, doi: 10.1007/s00300-016-2032-9.

Wright S.W., Jeffrey S.W., Mantoura R.F.C., Llewellyn C.A., Bjørnland T., Repeta D. \& Welschmeyer N. 1991. Improved HPLC method for the analysis of chlorophylls and carotenoids from marine phytoplankton. Marine Ecology Progress Series 77, 183-96, doi: 10.3354/meps077183.

Wulff A., Iken K., Quartino M.L., Al-Handal A., Wiencke C. \& Clayton M.N. 2011. Biodiversity, biogeography and zonation of marine benthic micro- and macroalgae in the Arctic and Antarctic. In C. Wiencke (ed.): Biology of polar benthic algae. Pp. 23-52. Berlin: De Gruyter.

Yuan Y., Westcott N., Gu J. \& Kitts D. 2009. Mycosporine-like amino acid composition of the edible red alga, Palmaria palmata (Dulse) harvested from the west and east coasts of Grand Manan Island, New Brunswick. Food Chemistry 112, 321-328, doi: 10.1016/j.foodchem.2008.05.066.

Zacher K., Rautenberger R., Hanelt D., Wulff A. \& Wiencke C. 2011. The abiotic environment of polar benthic algae. In C. Wiencke (ed.): Biology of polar benthic algae. Pp. 9-22. Berlin: De Gruyter. 